\title{
Fish stable isotope community structure of a Bahamian coral reef
}

\author{
Yiou Zhu' ${ }^{1}$. Steven P. Newman ${ }^{1,2} \cdot$ William D. K. Reid $^{1} \cdot$ Nicholas V. C. Polunin ${ }^{1}$
}

Received: 1 February 2019 / Accepted: 26 September 2019 / Published online: 11 November 2019

(c) The Author(s) 2019

\begin{abstract}
Stable isotopes have provided important insight into the trophic structure and interaction in many ecosystems, but to date have scarcely been applied to the complex food webs of coral reefs. We sampled white muscle tissues from the fish species composing $80 \%$ of the biomass in the $4-512 \mathrm{~g}$ body mass range at Cape Eleuthera (the Bahamas) in order to examine isotopic niches characterised by $\delta^{13} \mathrm{C}$ and $\delta^{15} \mathrm{~N}$ data and explore whether fish body size is a driver of trophic position based on $\delta^{15} \mathrm{~N}$. We found the planktivore isotopic niche was distinct from those of the other trophic guilds suggesting the unique isotopic baseline of pelagic production sources. Other trophic guilds showed some level of overlap among them especially in the $\delta^{13} \mathrm{C}$ value which is attributable to source omnivory. Surprising features of the isotopic niches included the benthivore Halichoeres pictus, herbivores Acanthurus coeruleus and Coryphopterus personatus and omnivore Thalassoma bifasciatum being close to the planktivore guild, while the piscivore Aulostomus maculatus came within the omnivore and herbivore ellipses. These characterisations contradicted the simple trophic categories normally assigned to these species. $\delta^{15} \mathrm{~N}$ tended to increase with body mass in most species, and at community level, the linear $\delta^{15} \mathrm{~N}-\log _{2}$ body mass relationship pointing to a mean predator-prey mass ratio of 1047:1 and a relatively long food chain compared with studies in other aquatic systems. This first demonstration of a positive $\delta^{15} \mathrm{~N}$-body mass relationship in a coral reef fish community suggested that the Cape Eleuthera coral reef food web was likely supported by one main pathway and bigger reef fishes tended to feed at higher trophic position. Such finding is similar to other marine ecosystems (e.g. North Sea).
\end{abstract}

\section{Introduction}

In coral reef food webs, fishes are typically categorised into strict trophic guilds (e.g. Hiatt and Strasburg 1960; Jennings et al. 1995; Polunin 1996; McClanahan et al. 1999; Hughes et al. 2003; MacNeil et al. 2015; D’Agata et al. 2016; Graham et al. 2017; Stamoulis et al. 2017; Hadi et al. 2018; Moustaka et al. 2018). Yet this may overlook trophoplasticity, where many species feed across trophic boundaries (e.g.

Responsible Editor: C. Trueman.

Reviewed by undisclosed experts.

Electronic supplementary material The online version of this article (https://doi.org/10.1007/s00227-019-3599-9) contains supplementary material, which is available to authorized users.

Yiou Zhu

mikezhugreenerworld@gmail.com

1 School of Natural and Environmental Sciences, Newcastle University, Newcastle upon Tyne NE1 7RU, UK

2 Banyan Tree Marine Lab, Vabbinfaru, North Malé Atoll, Republic of Maldives
Robertson 1982; Chen 2002) and thus their trophic functions and the overall functioning of the reef (Mouillot et al. 2014). Inaccurate trophic information jeopardises comprehensive understanding of these food webs. Traditional gut contents analysis gives detailed dietary information; however, this typically has high temporal and spatial variability (Jennings et al. 2001) and it might include items accidently ingested (e.g. eDNA in gut contents DNA bar coding; Leal and Ferrier-Pagès 2016). Stable isotopes provide a time-integrated signal of what has been assimilated from the diet (Jennings et al. 2001). The stable isotope ratio of carbon $\left({ }^{13} \mathrm{C} /{ }^{12} \mathrm{C}\right.$, expressed as $\delta^{13} \mathrm{C}$ ) is commonly used to distinguish production sources such as benthic and pelagic autotrophs (Tieszen et al. 1983; Bearhop et al. 2004), whereas the stable isotope ratio of nitrogen $\left({ }^{15} \mathrm{~N} /{ }^{14} \mathrm{~N}\right.$, expressed as $\left.\delta^{15} \mathrm{~N}\right)$ is used as a proxy for trophic position (TP) because it has a higher trophic enrichment factor (TEF) (DeNiro and Epstein 1978, 1981; McCutchan et al. 2003; Strieder Philippsen and Benedito 2013) and shows less variation at the baseline (Hesslein et al. 1991) than does carbon. Combining $\delta^{13} \mathrm{C}$ and $\delta^{15} \mathrm{~N}$ delineates 'isotopic niches' (Leibold 1995; Newsome et al. 2007) which inform feeding strategies and trophic 
interactions (Post 2002) at species, trophic guild and community levels (France et al. 1998; Jennings et al. 2001, 2002a, b; Al-Habsi et al. 2008). Combining these levels of data can explain a species' trophic ecology including how strict it is and what potential source(s) it is utilising with the latter being very important because trophic interactions among omnivorous species within the same community remain understudied in coral reefs.

Trophodynamics can be size based. In aquatic systems, large individuals generally feed at higher TPs (Jennings et al. 2001, 2002b; Al-Habsi et al. 2008; Romanuk et al. 2011). This is a result of ontogenetic dietary shifts, morphometric changes including increasing gape size, post-maturity factors and greater predator ability that influence foraging (Peters 1986; Jennings et al. 2001; Munday 2001; Jennings et al. 2002b; Al-Habsi et al. 2008; Newman et al. 2012; Robinson and Baum 2015; Ríos et al. 2019). However, some large fishes forage at lower TPs due to dietary shifts (e.g. Chen 2002; Layman et al. 2005), seasonality effects (Bronk and Glibert 1993; Rolff 2000) and human disturbance (Pastorok and Bilyard 1985). TPs of some species remain relatively unchanged with increasing body size (e.g. herbivores; PlassJohnson et al. 2013; Dromard et al. 2015). Size-based feeding remains almost unstudied in coral reef ecosystems (Robinson and Baum 2015) where large herbivores contribute greatly to the biomass.

Investigating TP to body mass relationships at community level can improve understanding of predator to prey relationships and energetic pathways (Romanuk et al. 2011; Robinson and Baum 2015) and of changes in community trophic composition (Graham et al. 2017). Where a positive TP relationship with body mass exists, the predator-prey mass ratio (PPMR) can be calculated. This reflects constraints on community structure (Trebilco et al. 2013) and can be used to evaluate general food web properties such as food chain length (Jennings and Warr 2003) and food chain transfer efficiency (Jennings et al. 2002c; Barnes et al. 2010) across different aquatic systems (Jennings et al. 2001, 2002c; Bode et al. 2003, 2006; Al-Habsi et al. 2008). The great diversity of production sources and trophic partitioning by consumers on coral reefs suggest that the PPMR may be smaller and food chains longer than in many other marine ecosystems. But to date, the community-level $\delta^{15} \mathrm{~N}$ to body mass relationship and the PPMR have not been reported for a coral reef, so important insights such as measures of food chain length cannot be gained.

Here, underwater visual census and stable isotope data were used to explore the role of body size and trophic interactions among fish species in structuring a coral reef fish community at Cape Eleuthera (the Bahamas). Specifically, the study aimed to: (1) define isotopic niches at species and trophic guild levels in order to understand the principal energy pathways supporting them; and (2) assess whether there are positive $\delta^{15} \mathrm{~N}$-body mass relationships at the species and community levels and if so, derive an average predator-prey biomass ratio (PPMR).

\section{Materials and methods}

\section{Study site}

Four accessible and conservation-protected reef sites (Fig. 1) on the Exuma side of Cape Eleuthera (the Bahamas) with

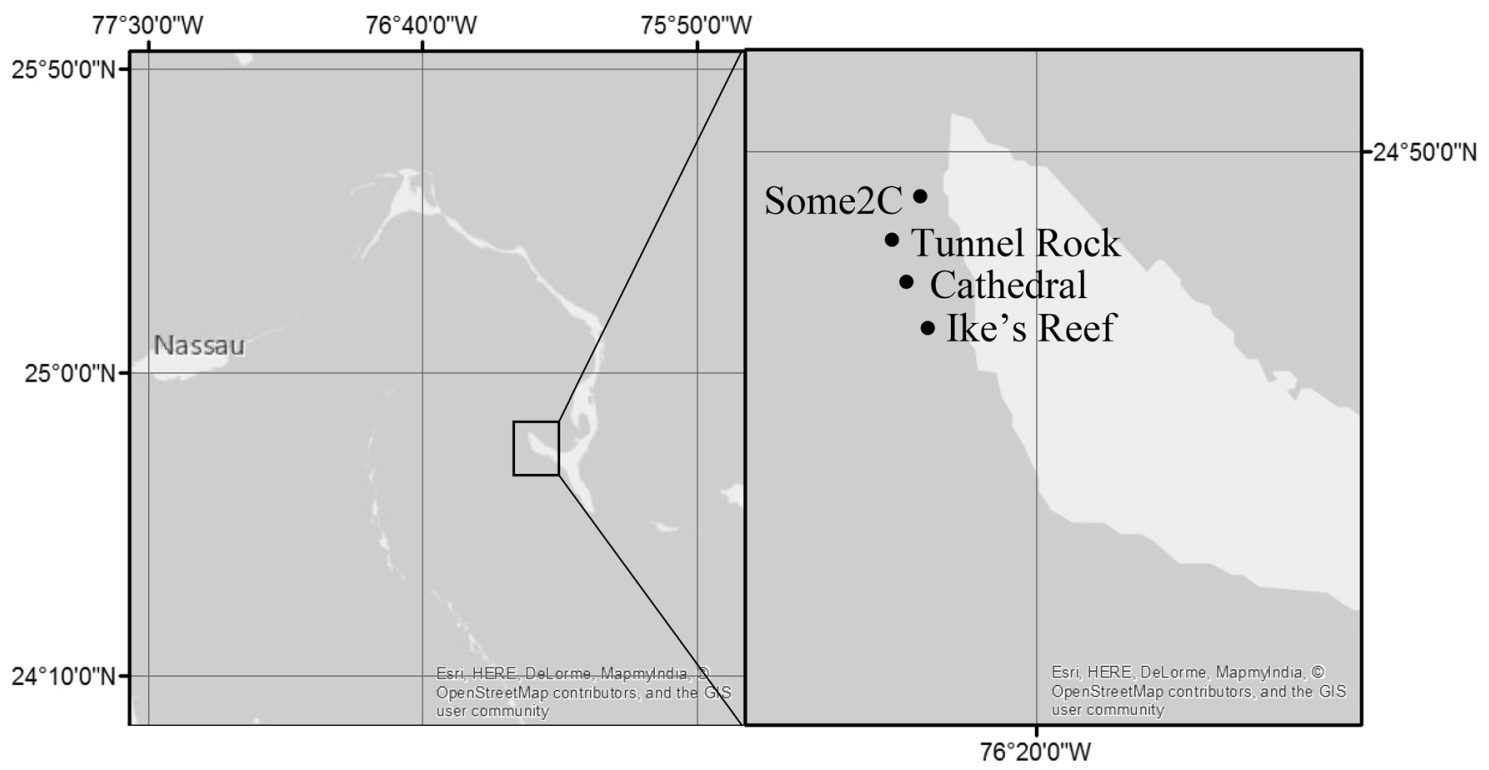

Fig. 1 Map of survey sites at Cape Eleuthera (the Bahamas) 
relatively high structural complexity and a diverse fish community were selected for visual surveys and fish sampling. These sites were close to each other and to shore and represented both bommies and patch reefs. In spite of the conservation status of the study sites, the reefs have been subject to chronic overfishing and otherwise impacted by cyclones and coral bleaching episodes.

\section{Fish survey}

Underwater visual census (UVC) was conducted by two divers using eight single-sweep $30 \mathrm{~m} \times 5 \mathrm{~m}$ transects at each site to record fish species, individual total length $(L$, to nearest $\mathrm{cm}$ ) and numbers of individuals. Surveyors' length estimation precision was repeatedly measured by conducting underwater fish-shaped object length estimation training (Bell et al. 1985) to minimise error $( \pm 5 \%)$. Transects ran parallel to each other to avoid intersection. Transects were carried out in the morning (9:30-11:30) or afternoon (14:00-16:00), while swimming at a steady speed for 30 min. Highly mobile transient individuals (e.g. sharks and jacks) were excluded since they had large home range and were not necessarily reef associated, and also large schools of fishes were excluded since they were sighted only sporadically (Ferreira et al. 2001).

\section{Sampling for stable isotope analysis}

Abundant species were selected by their contribution to the total biomass $(B)$. From UVC data, individual body mass values $(M, \mathrm{~g})$ were calculated from $L(\mathrm{~cm})$ using:

$M=a \times L^{b}$

with published length to weight conversion factors $a$ and $b$ ("Appendix A" in supplementary materials) from fishbase. org (Froese and Pauly 2017). Where conversion factors were linked with standard or fork length rather than $L$, or $L$ was in units other than centimetres, length was converted into appropriate units or length types using the equations in fishbase.org. All body mass data were $\log _{2}$ transformed to remove any effects of relationship between body size and phylogeny (Freckleton 2000). For each $M$ class (2-512 g), $B$ was calculated by summing individual $M$ values. Species were ranked in order of their contribution to the $B$ of each $\log _{2} \mathrm{M}$ interval, and those making up $80 \%$ of the $B$ were selected for the community trophic structure analysis.

Samples of selected species (Table 1) were collected through the length range recorded in the UVC to adequately describe species $\delta^{15} \mathrm{~N}-\log _{2} \mathrm{M}$ relationships (Galván et al. 2010). The size range cover ratio $\left(r_{\mathrm{L}}=L_{\mathrm{SIA} \text { sample }}\right.$ range $/ L_{\mathrm{UVC}}$ range) was used to check whether the sampling objective was met. Fish were collected using a variety of techniques depending on their behaviour towards divers, feeding habits and swimming patterns. Hand net, gill net (mesh size: $1 \mathrm{~cm} \times 1 \mathrm{~cm}$, net size: $2 \mathrm{~m} \times 1 \mathrm{~m}$ ), BINCKE net (Anderson and Carr 1998), underwater fishing hook and line, static hook and line, spearfishing (local fishermen only) and hook and line surface trolling were all used in the sampling in the survey sites and adjacent areas (Table 2). Fish were killed by spine dislocation and stored in an ice chest on board. Samples were all collected within a 1-month period and from nearby sites to reduce spatial and temporal isotopic variation (Bronk and Glibert 1993; Jennings et al. 1997; Rolff 2000; McCutchan et al. 2003).

After landing, approximately $2 \mathrm{~g}$ of dorsal white muscle tissue near the dorsal fin were dissected, rinsed with water and stored in individual whirlpack bags in a $-20{ }^{\circ} \mathrm{C}$ freezer, and algal samples were only rinsed and stored in a freezer. All samples were dried in individual tin trays in an oven at $40{ }^{\circ} \mathrm{C}$ for $\sim 12 \mathrm{~h}$ until fully dried and then in individual sealed Eppendorf tubes in zip-lock bags.

\section{Stable isotope analysis preparation}

All dried samples were imported to Newcastle University, freeze dried and then manually ground with mortar and pestle. Fish samples were weighed to $1.0 \pm 0.1 \mathrm{mg}$ in tin capsules with a Mettler MT5 microbalance. The prepared samples were analysed by Iso-Analytical Ltd (Crewe, UK) by Elemental Analysis-Isotope Ratio Mass Spectrometry (EA-IRMS). The ${ }^{15} \mathrm{~N} /{ }^{14} \mathrm{~N}$ ratio $\left(\delta^{15} \mathrm{~N}\right)$ was expressed relative to $\mathrm{N}_{2}$ in air for nitrogen, while that of ${ }^{13} \mathrm{C} /{ }^{12} \mathrm{C}\left(\delta^{13} \mathrm{C}\right)$ was relative to Pee Dee Belemnite (PDB) of $\mathrm{CO}_{2}$. Reference material used for this analysis was IA-R042 $\left(\delta^{13} \mathrm{C}=-21.6 \pm 0.1 \% o, \delta^{15} \mathrm{~N}=7.6 \pm 0.1 \% o\right)$, with quality control check samples IA-R042, IA-R038 $\left(\delta^{13} \mathrm{C}=-25.0 \pm 0.1 \% o, \delta^{15} \mathrm{~N}=-0.4 \pm 0.1 \%\right.$ $)$, a mixture of IA-R006 $\left(\delta^{13} \mathrm{C}=-11.7 \pm 0.0 \%\right)$ and IA-R046 $\left(\delta^{15} \mathrm{~N}=21.9 \pm 0.2 \%\right.$ ) . IAR042 and IA-R038 were calibrated against and traceable to IAEA-CH- $6\left(\delta^{13} \mathrm{C}=-10.4 \% o\right)$ and IAEA-N-1 $\left(\delta^{15} \mathrm{~N}=0.4 \%\right)$, IA-R006 to IAEA-CH- 6 and IA-R046 to IAEA-N-1. External standards (fish white muscle tissue, $\delta^{13} \mathrm{C}=-18.9 \pm 0.0 \%$ o, $\delta^{15} \mathrm{~N}=12.9 \pm 0.1 \%$ ) were also used for future reference. The precision of analysis for $\delta^{13} \mathrm{C}, \delta^{15} \mathrm{~N}, \% \mathrm{C}$ and $\% \mathrm{~N}$ was $\pm 0.1 \%, \pm 0.2 \%, \pm 4 \%$ and $\pm 1 \%$, respectively. For individual samples, no lipid extraction was needed because their $\mathrm{C} / \mathrm{N}$ ratios were less than 3.7 (Fry et al. 2003; Sweeting et al. 2006).

\section{Data analysis}

All data were tested for normality and homogeneity of variance prior to analysis and analysed in $R 3.24$ (R Core Team 2016) using the package siar (Parnell and Jackson 2013) between $\delta^{13} \mathrm{C}$ and $\delta^{15} \mathrm{~N}$ data, linear regression (Wilkinson and Rogers 1973; Bates et al. 1992) between $\delta^{15} \mathrm{~N}$ and $\log _{2}$ 


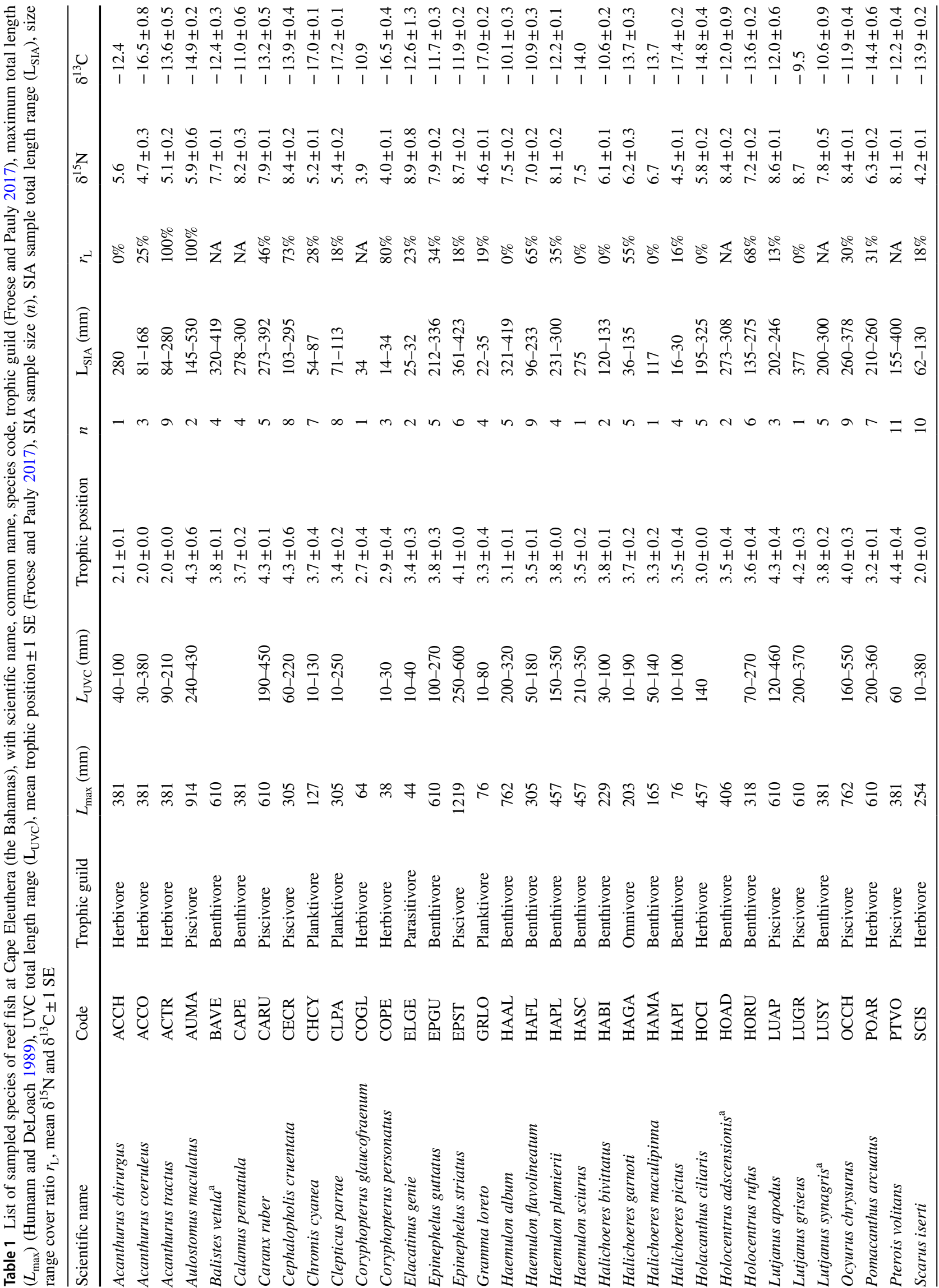




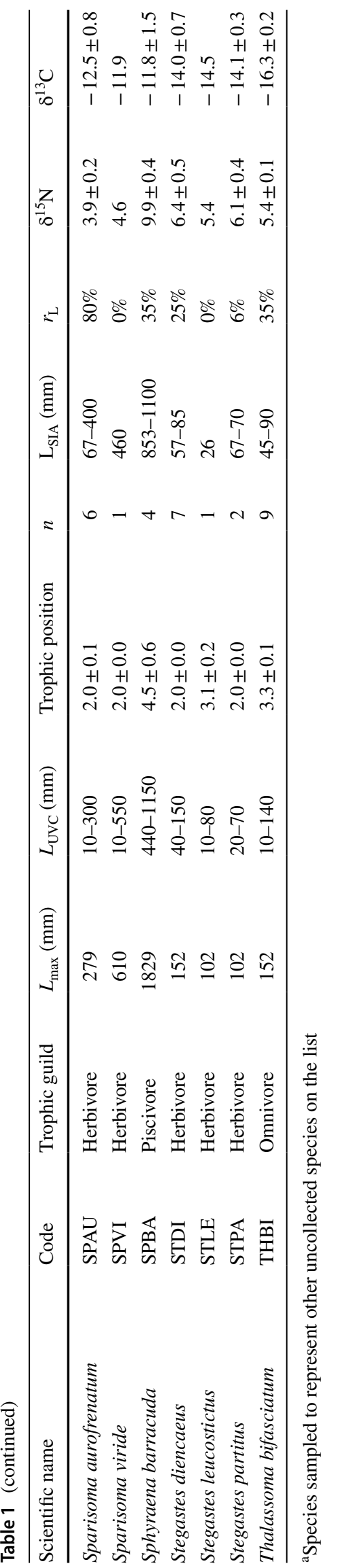

body mass and mvtnorm to simulate values from a bivariate normal distribution. Results were visualised using ggplot2 (Wickham and Chang 2016). The assumptions of the ordinary least squares linear regression analyses were assessed with QQ plots, histograms of standardised residuals and plots of standardised residuals versus fitted values. Pearson's correlation coefficient was used to test correlations between variables. Significance was set at $p=0.05$ in all cases. All errors are reported as $\pm 1 \mathrm{SE}$ unless otherwise stated.

\section{Species and trophic guild stable isotope analyses}

The bulk $\delta^{13} \mathrm{C}$ and $\delta^{15} \mathrm{~N}$ data were used to interpret $\delta{ }^{15} \mathrm{~N}-\delta^{13} \mathrm{C}$ relationships in each species and trophic guild (Froese and Pauly 2017). Isotopic niches of five trophic guilds (four benthic: benthivore, herbivore, omnivore and piscivore and one pelagic: planktivore) were investigated using SIBER in the siar package. This was achieved by investigating standard ellipse parameters: eccentricity $(E)$ and the angle in degrees $\left(\theta, 0^{\circ}-180^{\circ}\right)$ between semi-major axis and the $x$ axis, the sample size corrected standard ellipse areas $\left(\mathrm{SEA}_{\mathrm{C}}\right)$ and Bayesian standard ellipse areas ( $\mathrm{SEA}_{\mathrm{B}}$ ) (Jackson et al. 2011). $\theta$ and $E$ values potentially distinguish among isotopic niches where different trophic guilds have similar sized $\mathrm{SEA}_{\mathrm{C}}$ but different relationships between $\delta^{13} \mathrm{C}$ and $\delta^{15} \mathrm{~N}$ (Reid et al. 2016). $\theta$ values close to $0^{\circ}$ or $90^{\circ}$ suggest dispersion in only one axis: $\theta$ values close to $0^{\circ}$ represent relative dispersion along the $x$ axis $\left(\delta^{13} \mathrm{C}\right)$, indicating multiple production sources, while $\theta$ values close to $90^{\circ}$ highlight relative dispersion along the $y$ axis $\left(\delta^{15} \mathrm{~N}\right)$, indicating feeding across multiple trophic positions from a uniform basal source. $E$ explains the variance on the $x$ and $y$ axes: low $E$ refers to similar variance on both axes with a more circular shape, while high $E$ indicates that the isotopic niche is stretched along either $x$ or $y$ axis. The overlap of the standard ellipses between guilds was calculated using "sea. overlap" using SIBER. In order to compare isotopic niche areas among trophic guilds, a Bayesian approach was used that calculated 20,000 posterior estimates of $\mathrm{SEA}_{B}$ based on the data set. The mode and $95 \%$ credible intervals (CI) were reported. A significant difference among $\mathrm{SEA}_{\mathrm{B}}$ was interpreted graphically whereby if the $95 \%$ CI did not overlap, then the $\mathrm{SEA}_{\mathrm{B}}$ were deemed to be significantly different (Parnell and Jackson 2013).

\section{$\delta^{15} \mathrm{~N}$-body size relationship}

Cross-species relationships between stable isotope data and $M$ were analysed using linear regression between mean bulk $\delta^{13} \mathrm{C}$ and $\delta^{15} \mathrm{~N}$ of each species and their maximum body mass $\left(M_{\max }\right)$ recorded by Humann and DeLoach (1989). Comparing fishes at a fixed proportion of maximum size (here $\geq 55 \%$ of 
Table 2 List of fishing method and targeting species

\begin{tabular}{lll}
\hline Fishing method & Targeting species & Examples of species \\
\hline Hand net & Slow, approachable, small, cryptic, territorial & Gobies, damselfish, PTVO, AUMA \\
$1 \mathrm{~cm} \times 1 \mathrm{~cm}$ gill net & Fast, alert, non-thread shaped, schooling & J. Scarinae, A. labrids, J. haemulids, pomacentrids \\
BINCKE net & Fast swimming, close to substrate, schooling & J. Scarinae, labrids \\
Underwater fishing & Large bodied, fast swimming, cryptic, smart and alert & A. haemulids, HORU, some Scarinae, lutjanids, grouper \\
Line and hook & Pelagic, fast, alert & Carangids, lutjanids \\
Spearfishing & Fast, aggressive & A. Scarinae, acanthurids, PTVO \\
Surface troll & Pelagic, fast swimming individuals & Carangids, SPBA \\
\hline
\end{tabular}

$J$ juvenile, $A$ adult, for codes see Table 1

$L_{\max }$ ) reduced the risk of comparing different life stages (Charnov 1993; Jennings et al. 2001; Galván et al. 2010).

For each species, the $\delta^{15} \mathrm{~N}-\log _{2} \mathrm{M}$ relationship was generated using linear regression, the slope and intercept values being used to calculate $\delta^{15} \mathrm{~N}$ values of individuals of the same species with other body mass values. To derive the community relationship between $\delta^{15} \mathrm{~N}$ and $\log _{2} \mathrm{~B}(B$ was used instead of $M$ to differentiate the community-level analysis from the species-level analysis), the mean weighted $\delta^{15} \mathrm{~N}$ value of each $\log _{2} \mathrm{~B}$ class was derived by calculating (1) the mass ratio $(r)$ of each individual $(i)$ in each $\log _{2} \mathrm{~B}$ class, using $r_{i}=M_{i} / \sum_{i=1}^{n} M_{i}$, where $n$ is the total number of individuals in the $\log _{2} \mathrm{~B}$ class; and (2) mean weighted $\delta^{15} \mathrm{~N}$ for each $\log _{2} \mathrm{~B}$ class $j$ of the whole community as $\delta^{15} \mathrm{~N}_{j}=\sum_{i=1}^{n} \delta^{15} \mathrm{~N}_{i} \times r_{i}$ (Al-Habsi et al. 2008). The $\delta^{15} \mathrm{~N}$ of each individual $\left(\delta^{15} \mathrm{~N}_{\mathrm{i}}\right)$ was either calculated using the species-level linear $\delta^{15} \mathrm{~N}-\log _{2} \mathrm{M}$ relationship if it is significant or equivalent to the mean $\delta^{15} \mathrm{~N}$ of the species if not.

Because of the species richness of these reefs and limitation of fishing techniques, not all species could be sampled. To obtain $\delta^{15} \mathrm{~N}$ values of such species, several methods were used (full details in "Appendix B" supplementary materials): (1) using samples from similar species within the same genus if possible (order of priority: same genus, family, site, trophic position, diet and feeding habit from fishbase.org) by comparing 3 criteria: (a) length to weight conversion factors, (b) dietary similarities and (c) their feeding behaviours in this area; and (2) using existing data in the literature from nearby locations or elsewhere in the Caribbean with baseline adjustment ( $D$. cavernosa to $D$. cavernosa if possible, otherwise $D$. cavernosa to turf algae) to reduce temporal and/ or spatial baseline variations (Cabana and Rasmussen 1996).

\section{Predator-prey mass ratio}

The mean PPMR was calculated using the slope $(b)$ of the regression line of the TP- $\log _{2} \mathrm{~B}$ relationship as PPMR $=2^{1 / b}$. TP was calculated using the additive framework as
$\mathrm{TP}=\mathrm{TP}_{\text {base }}+\frac{\delta^{15} \mathrm{~N}_{\text {fish }}-\delta^{15} \mathrm{~N}_{\text {base }}}{\Delta \delta^{15} \mathrm{~N}}$

where the $\Delta \delta^{15} \mathrm{~N}$ is assumed constant and equal to $3.4 \%$ o (DeNiro and Epstein 1981; Minagawa and Wada 1984). $\mathrm{TP}_{\text {base }}$ was indicated by the striped parrotfish (S. iserti, $\delta^{15} \mathrm{~N}_{\text {base }}=4.2 \pm 0.1 \%$; $\mathrm{TP}_{\text {base }}=2.0$ ) due to its low isotopic variation across sizes, time integration of seasonality from producers and adequate sample size $(n=10)$. The slope $(b)$ of TP- $\log _{2} \mathrm{~B}$ relationship was obtained from the slope $(s)$ of $\delta^{15} \mathrm{~N}-\log _{2} \mathrm{~B}$ relationship where $b=s / 3.4$. Thus, the PPMR is calculated as

PPMR $=2^{3.4 / s}$.

The uncertainty of PPMR was estimated by (1) simulating 10,000 times of independent variables $s$ (the mean and standard deviation from the linear regression statistics) and $\Delta \delta^{15} \mathrm{~N}$ values (mean and standard deviation of $3.4 \pm 1.0 \%$; Post 2002) from a bivariate normal distribution $(\rho=0)$ and (2) calculating PPMR estimates using Eq. 3. The median, 25 th and 75 th quantiles were reported. The same method was applied to existing studies for comparison.

\section{Results}

\section{Isotopic niches at species and trophic guild levels}

In total 9055 individuals ( $L$ from 1 to $120 \mathrm{~cm}, M$ from 0.01 to $2742 \mathrm{~g}$ ) were recorded in $32 \mathrm{UVCs}$ over $4800 \mathrm{~m}^{2}$ of reef. Of 41 fish species collected and analysed for $\delta^{15} \mathrm{~N}, 11$ had sample sizes under three, and three (Coryphopterus glaucofraenum, Balistes vetula, Holocentrus adscensionis) were sampled to represent certain uncollected species. The size range cover ratio $\left(r_{\mathrm{L}}\right)$ ranged from 0 to $100 \%$ (mean $=31.0 \pm 5.0 \%$ ). Mean species $\delta^{13} \mathrm{C}$ ranged from $-17.4 \pm 0.2 \%$ (Halichoeres pictus) to $-9.5 \pm 0.0 \%$ o (Lutjanus griseus), while mean $\delta^{15} \mathrm{~N}$ ranged from $3.9 \pm 0.8 \%$ (S. aurofrenatum) to $9.9 \pm 1.5 \%$ o (Sphyraena barracuda). $\delta^{15} \mathrm{~N}$ values were significantly but weakly correlated with $\delta^{13} \mathrm{C}\left(p<0.05, r_{\text {adjusted }}^{2}=0.29\right)$ at the species level 


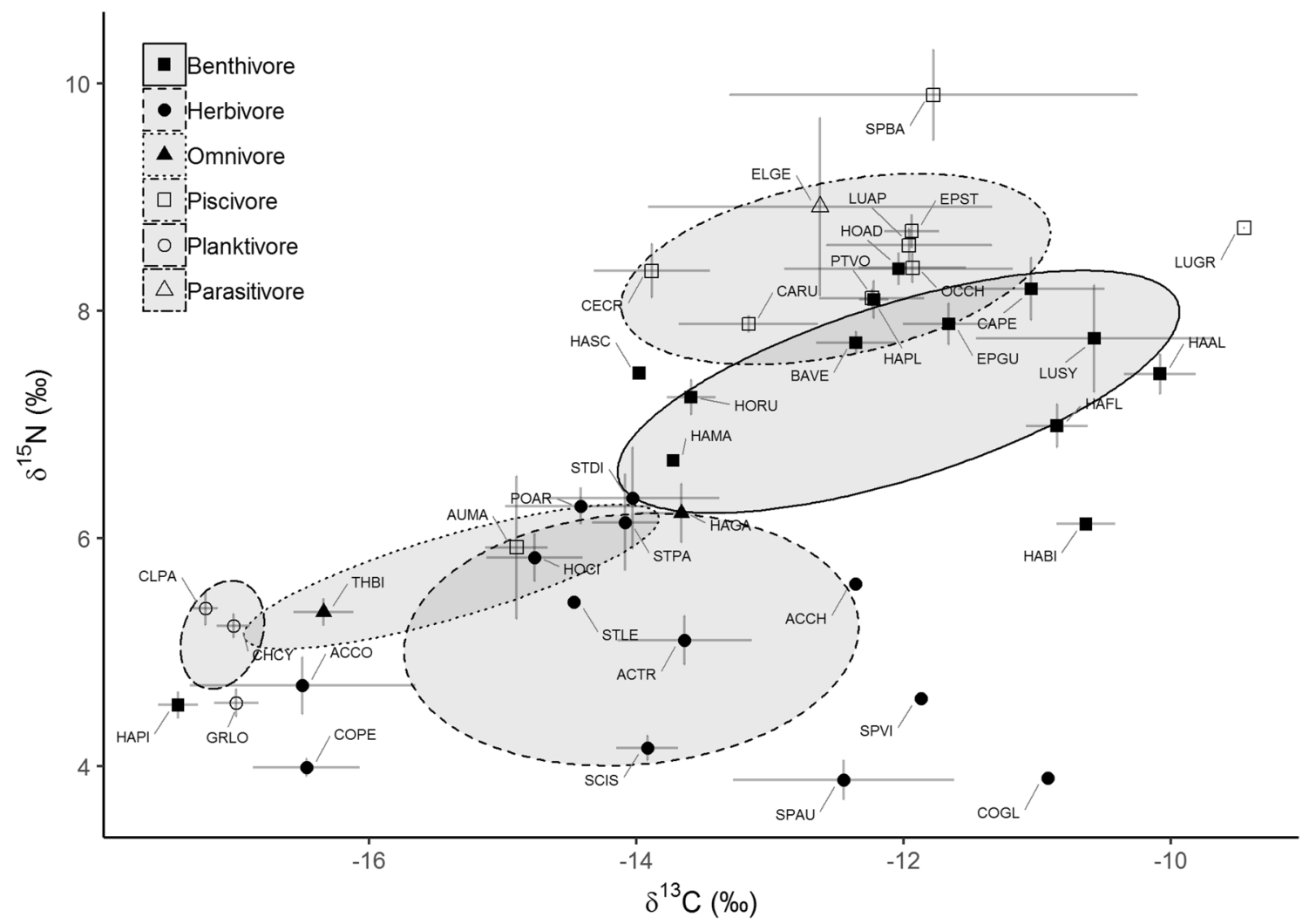

Fig. 2 Plot of bulk $\delta^{15} \mathrm{~N}$ against $\delta^{13} \mathrm{C}$ (mean $\pm \mathrm{SE}$ ) of all sampled fish species (for codes see Table 1) and standard ellipses (solid line-ellipses) for five trophic guilds (and one species of parasitivore, ELGE) of fish at Cape Eleuthera (the Bahamas)

(Fig. 2). Some species had large SE values in $\delta^{13} \mathrm{C}(\geq 1 \%$ o (e.g. S. barracuda) or $\delta^{15} \mathrm{~N}(\geq 0.5 \%$ o) (e.g. Aulostomus maculatus), or both $\delta^{13} \mathrm{C}$ and $\delta^{15} \mathrm{~N}$ (e.g. Elacatinus genie). Mean $\delta^{13} \mathrm{C}$ and $\delta^{15} \mathrm{~N}$ values of strict pelagic planktivores (e.g. Chromis cyanea, $\mathrm{TP}=3.7, \quad \delta^{13} \mathrm{C}=-17.0 \pm 0.1 \%$, $\delta^{15} \mathrm{~N}=5.2 \pm 0.1 \%$ ) and strict benthivores of similar TP (e.g. B. vetula, $\mathrm{TP}=3.8, \delta^{13} \mathrm{C}=-12.4 \pm 0.3 \%$ o, $\delta^{15} \mathrm{~N}=7.7 \pm 0.1 \%$ o) were significantly different.

The herbivore and benthivore guilds had the largest isotopic niches, followed by the piscivore guild, and then the omnivore guild; the planktivore guild had an isotopic niche significantly smaller than others (Table 3 ). The planktivore guild had a lower $\delta^{13} \mathrm{C}$ than others and was separated from the herbivore, benthivore and piscivore trophic guilds (Fig. 2, Table 4). The isotopic niche of the omnivores overlapped with those of the herbivores and planktivores as did those of the benthivore and piscivore (Table 4). The isotopic niche of the herbivores was vertically separated from those of the benthivores and piscivores. $E$ and $\theta$ values differed among trophic guilds (Table 3 ); the herbivore guild had the lowest $E(0.77)$, while the omnivores had the highest (0.98). The benthivore (0.94) and planktivore (0.79) trophic guilds had $E$ values very similar to those of the omnivore and herbivore trophic guilds, respectively.
Table 3 Isotopic niche area $\left(\%{ }^{2}\right)$ estimates and parameters [eccentricity $(E)$, the angle in degree between the semi-major axis of the standard ellipse and the $x$ axis $(\theta)$ for five trophic guilds (benthivore, herbivore, omnivore, piscivore and planktivore) of coral reef fish at Cape Eleuthera (the Bahamas)]

\begin{tabular}{lllrll}
\hline $\begin{array}{l}\text { Trophic } \\
\text { guild }\end{array}$ & $\mathrm{SEA}_{\mathrm{C}}\left(\% o^{2}\right)$ & $E$ & $\theta\left(^{\circ}\right)$ & $\mathrm{SEA}_{\mathrm{B}}\left(\%{ }^{2}\right)$ & $\mathrm{SEA}_{\mathrm{B}} 95 \% \mathrm{CI}$ \\
\hline Benthivore & 5.30 & 0.94 & 20.96 & 5.19 & $3.96-6.93$ \\
Herbivore & 5.90 & 0.77 & 6.29 & 5.73 & $4.32-7.53$ \\
Omnivore & 1.83 & 0.98 & 19.17 & 1.77 & $1.05-3.14$ \\
Piscivore & 3.91 & 0.89 & 14.36 & 3.81 & $2.88-4.04$ \\
Planktivore & 0.46 & 0.79 & 75.69 & 0.41 & $0.26-0.66$ \\
\hline
\end{tabular}

Estimates of isotopic niche areas are given as $\left(\mathrm{SEA}_{\mathrm{C}}\right)$ and the mode of the Bayesian standard ellipse area $\left(\mathrm{SEA}_{\mathrm{B}}\right)$ estimates. Upper and lower $95 \%$ credible intervals $(\mathrm{CI})$ indicate the uncertainty in the $\mathrm{SEA}_{\mathrm{B}}$ estimates

Table 4 Standard ellipse overlap $\left(\% o^{2}\right)$ among the five trophic guilds

\begin{tabular}{lllll}
\hline Trophic guild & Benthivore & Herbivore & Omnivore & Piscivore \\
\hline Herbivore & 0.00 & & & \\
Omnivore & 0.00 & 0.77 & & \\
Piscivore & 0.57 & 0.00 & 0.00 & \\
Planktivore & 0.00 & 0.00 & 0.03 & 0.00 \\
\hline
\end{tabular}


The $\theta$ values of the $\delta^{15} \mathrm{~N}$ versus $\delta^{13} \mathrm{C}$ relationships of all the trophic guilds were positive; the herbivores had the lowest $\theta\left(6^{\circ}\right)$, while the planktivores had the highest $\left(76^{\circ}\right)$. Among the benthivore, omnivore, piscivore and herbivore trophic guilds, the isotopic niche was spread along the $x$ axis $\left(\theta<45^{\circ}\right)$, while that of the planktivores was more vertically spread $\left(\theta>45^{\circ}\right)$. Some species (the benthivore H. pictus, herbivores Acanthurus coeruleus and Coryphopterus personatus and omnivore Thalassoma bifasciatum) had isotopic coordinates close to the ellipse of the planktivore trophic guild, and one piscivore (A. maculatus) had an isotopic coordinate within the standard ellipse of the herbivore trophic guild.

\section{$\delta^{15} \mathrm{~N}$-body mass relationships at species and community levels and PPMR}

There were significant but weak relationships across species between $\log _{2} M_{\max }$ (maximum body mass) and both $\delta^{15} \mathrm{~N}\left(r_{\text {adjusted }}^{2}=0.12, p<0.05\right.$; Fig. $\left.3 \mathrm{a}\right)$ and $\delta^{13} \mathrm{C}$ data $\left(r_{\text {adjusted }}^{2}=0.17, p<0.05\right.$; Fig. $3 \mathrm{~b}$ ). The $\delta^{15} \mathrm{~N}$ values of several species did not scale positively with $\log _{2} M_{\max }$ (e.g. $E$.
Fig. 3 Plots of bulk $\delta^{15} \mathrm{~N}(\mathbf{a})$ and bulk $\delta^{13} \mathrm{C}(\mathbf{b})($ mean $\pm \mathrm{SE})$ versus $\log _{2}$ maximum body mass for all collected fish species (for codes see Table 1) at Cape Eleuthera with mean isotope values of individuals bigger than $55 \%$ of their $L_{\max }$. Solid line: linear regression line $(p<0.05)$
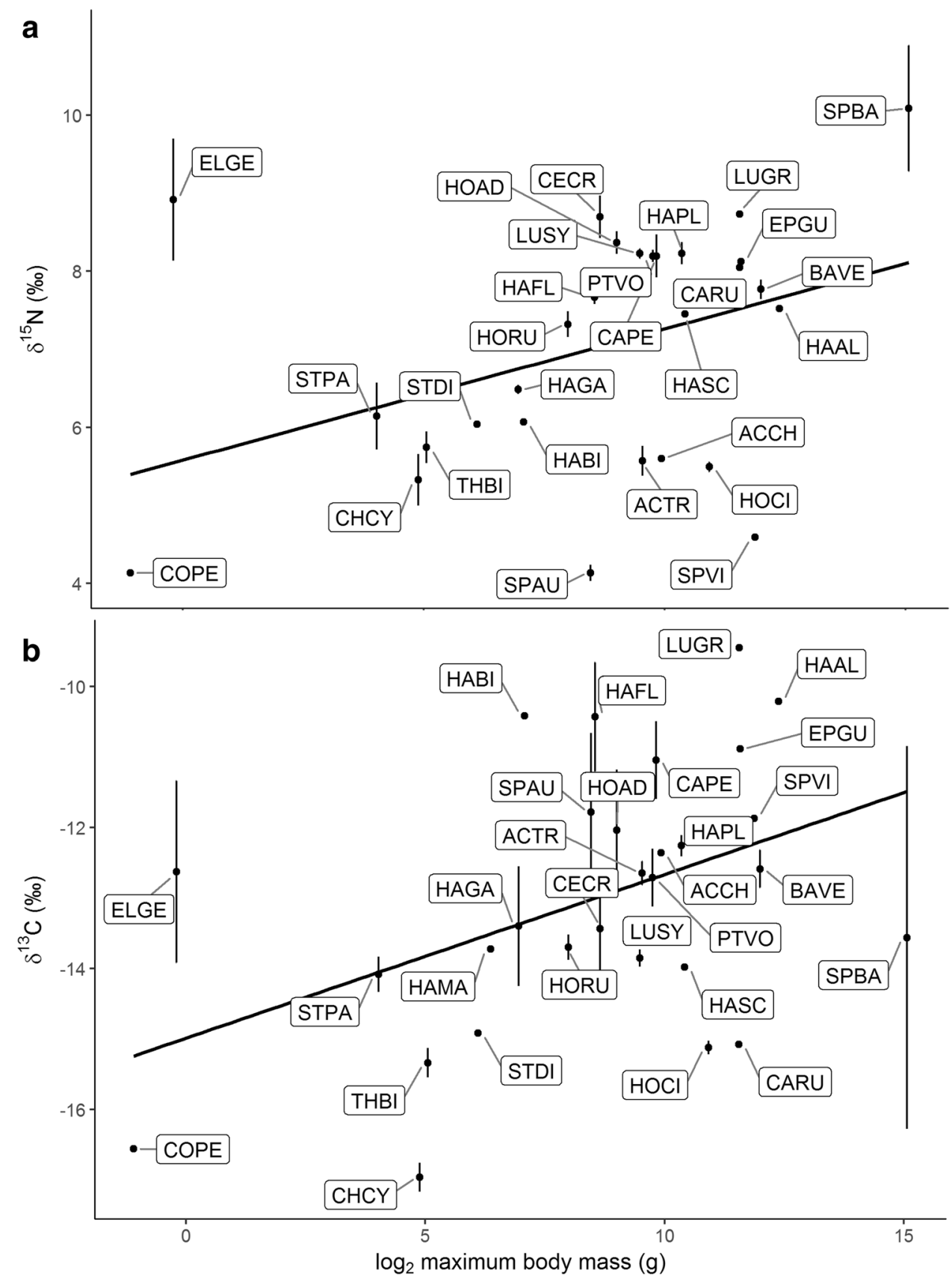
genie, Sparisoma viride, Scarus iserti and S. aurofrenatum). The $\mathrm{SE}$ values of $\delta^{13} \mathrm{C}$ were generally higher than those of $\delta^{15} \mathrm{~N}$ regardless of $M_{\max } . \delta^{15} \mathrm{~N}$ tended to vary with $\log _{2} \mathrm{M}$ for 29 species (Fig. 4) with $n \geq 3$; of these 24 relationships were positive (significantly so, e.g. C. cyanea), while five were negative (significantly so, e.g. Pomacanthus arcuatus, "Appendix C" supplementary materials). There was considerable variability around the regression line for nine species $\left(r_{\text {adjusted }}^{2}<0.5\right.$, e.g. S. barracuda), whereas this was not the case for others (e.g. Clepticus parrae, Calamus pennatula, Halichoeres garnoti). At the community level, the combined isotope data demonstrated a strong positive linear relationship between mean $\delta^{15} \mathrm{~N}$ and $\log _{2} \mathrm{~B}$, the regression equation being $\delta^{15} \mathrm{~N}=0.34 \pm 0$. $04 \log _{2} \mathrm{~B}+4.03 \pm 0.24\left(r_{\text {adjusted }}^{2}=0.64, p<0.05\right.$, Fig. 5). The slope value of TP- $\log _{2} \mathrm{~B}$ was $b=0.10\left(r_{\text {adjusted }}^{2}=0.80\right.$, $p<0.05$ ), and the PPMR estimates were 1047:1 (Table 5).
Fig. 4 Plot of $\delta^{15} \mathrm{~N}$ versus $\log _{2}$ body mass (linear regression) of all sampled species at Cape Eleuthera (the Bahamas). Solid line: significant relationship $(p<0.05)$, dashed line: nonsignificant relationship. For codes see Table 1
Fig. 5 Plot of combined relationship (linear regression) between $\delta^{15} \mathrm{~N}$ and $\log _{2}$ body mass at Cape Eleuthera (the Bahamas). Solid line: linear regression line $(p<0.05)$, long dashed line: $95 \%$ CI
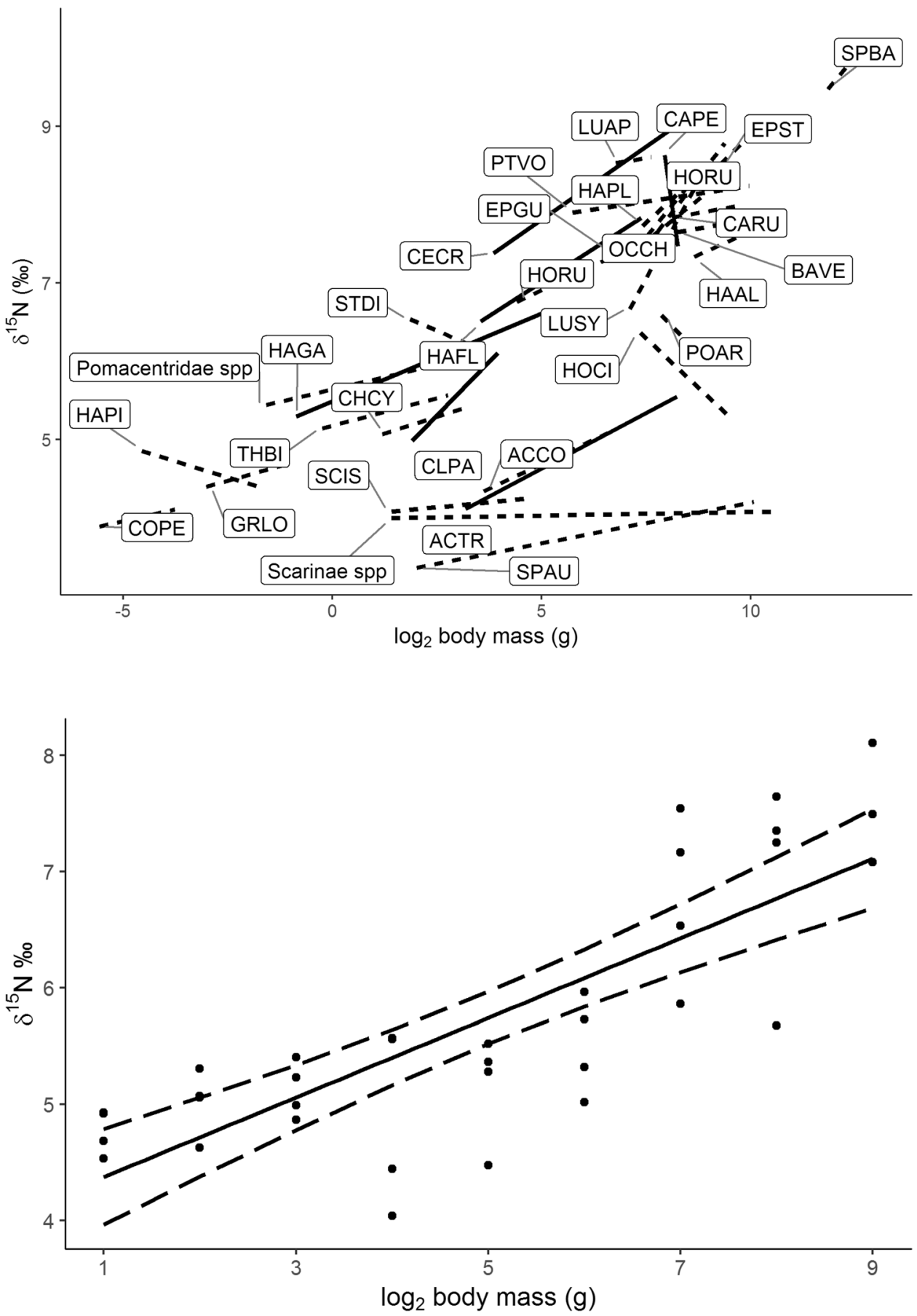
Table 5 Mean PPMR values of different communities from the literature using the additive framework

\begin{tabular}{llll}
\hline Community & \multicolumn{2}{l}{ PPMR estimates } & \multirow{2}{*}{ Reference } \\
\cline { 2 - 3 } & Median & 25th and 75th quantiles & \\
\hline Central North Sea & $104: 1$ & 42 to $75: 1$ & Jennings et al. (2002a, b) \\
Northern North Sea & $1037: 1$ & 239 to 4503 & Jennings et al. (2001) \\
Cape Eleuthera & $1047: 1$ & 250 to $4833: 1$ & Present study \\
Puget Sound & $4320: 1$ & 779 to $2.71 \times 10^{4}: 1$ & Reum et al. (2015) \\
North Sea & $8349: 1$ & 1235 to $6.73 \times 10^{4}: 1$ & Jennings and Warr (2003) \\
Western Arabian & $8935: 1$ & 1287 to $6.60 \times 10^{4}: 1$ & Al-Habsi et al. (2008) \\
Iberian Peninsula & $2.02 \times 10^{7}: 1$ & $2.27 \times 10^{5}$ to $1.61 \times 10^{10}: 1$ & Bode et al. (2006) \\
\hline
\end{tabular}

\section{Discussion}

\section{Species and trophic guild trophodynamics}

Stable isotope data at both species and trophic guild levels indicated that at the Cape Eleuthera site there were large differences in trophic ecology within and among species, and species utilising a range of production source types were common.

High within-species variability in $\delta^{13} \mathrm{C}$ and $\delta^{15} \mathrm{~N}$ values for some species suggested the existence of individual specialisation (Matthews and Mazumder 2004) in the food web where different individuals of the same species were consistently sampling different production sources. For example, similarly sized individuals of the apex predator $S$. barracuda had similar $\delta^{15} \mathrm{~N}$ values but differed greatly in $\delta^{13} \mathrm{C}$ values. The $\delta^{13} \mathrm{C}$ value of approximately $-16 \%$ o was close to that within the planktivore trophic guild, while the $\delta^{13} \mathrm{C}$ value of $-10 \%$ was more consistent with the piscivore trophic guild. Trophic position omnivory indicated by differences in $\delta^{15} \mathrm{~N}$ also occurs, for example, in the parasitivore E. genie which feeds on parasites from fish at different trophic positions.

The SIBER analysis indicated at least two types of production sources, namely benthic (e.g. algae) and pelagic (e.g. plankton), and mixed-feeding patterns for some species that are typically regarded as relying solely on single types of source materials (e.g. herbivorous fish; Plass-Johnson et al. 2013; Dromard et al. 2015). In this study, isotopic niche areas of the planktivores were significantly smaller than other guilds even though plankton can have highly variable isotopic signatures (McClelland and Montoya 2002; Kürten et al. 2013), which indicated a level of dietary strictness or consistency. High $\theta$, low $E$ and low SEA values of the planktivore guild nevertheless suggested TP omnivory, with these fish feeding at different TPs albeit from the same type of pelagic source (e.g. phytoplankton and zooplankton). The omnivore guild had high $E$, low $\theta$ and SEA values, the $\delta^{13} \mathrm{C}$ data indicating that the two species are supported by plankton and benthic algae with similar $\delta^{15} \mathrm{~N}$ baselines. Although based on only two species, the omnivores may be connecting these two pathways to some extent (McMeans et al. 2016). The benthivore, piscivore and herbivore trophic guilds, which share mostly benthic production sources, had similar isotopic niche areas which were much greater than those of the planktivores and omnivores, with their isotopic niches spread along the $x$ axis as indicated by $E$ and $\theta$ values, suggesting source omnivory within the benthic producer category. Overlapping isotopic niches among the trophic guilds (e.g. piscivore and benthivore) suggested that they might share dietary resources to some extent; for example, some lutjanids are both piscivorous and feed on zoobenthos (Allen 1985; Kulbicki et al. 2005; Layman and Allgeier 2012). The vertical distribution in the isotopic niches for the four benthic trophic guilds reflected the herbivorous fish feeding at low trophic positions, while the omnivores, benthivores and piscivores utilised a wider range of energy sources from different TPs. There were species with stable isotope values outside the isotopic niches of their assumed trophic guilds, which suggested feeding on different food sources than previously known or those derived from snapshot diet studies. For example, the four benthic feeders (H. pictus, A. coeruleus, $C$. personatus and $T$. bifasciatum) were likely relying on plankton sources, and the piscivore A. maculatus might be predating on smaller herbivores. Some herbivores came partly within the isotopic niches of other trophic guilds, indicating feeding on food sources in addition to algae such as invertebrates or planktivore faeces (Robertson 1982; Wulff 1997; Dunlap and Pawlik 1998; Chen 2002; Plass-Johnson et al. 2013). This can only be confirmed with detailed dietary analysis including baseline variation (i.e. during the 3-6 months isotopic turn over period).

\section{$\delta^{15} \mathrm{~N}$-body mass relationship}

The majority of species had a positive trend between $\delta^{15} \mathrm{~N}$ and $\log _{2} \mathrm{M}$ indicating that they tend to feed at higher TPs as size increases. This could be a result of increasing gape size, predatory skill and fitness level allowing individuals to feed on higher TP prey as they grow (Peters 1986; Munday 2001; Newman et al. 2012). Those with negative or highly variable stable isotope-size relationships potentially have dietary shifts from isotopically high value production sources to 
low or multi-pathway (e.g. exploitation of short food chain) feeding patterns in their sampled size ranges, or otherwise assimilating significantly different isotopic baselines across the population (Jennings et al. 2002a; Layman et al. 2005). Unlike Robinson and Baum (2015) where $\delta^{15} \mathrm{~N}-\log _{2} \mathrm{M}$ relationships of all individuals in two separate trophic pathways (herbivore and carnivore) were investigated, species-level and whole-community-level analyses were conducted in this study. The variation among species is attributable to differences in the trophic pathways supporting them, but to understand better how trophic pathways affect such relationships, more data are clearly needed. At community level, a positive linear relationship between $\delta^{15} \mathrm{~N}$ and $\log _{2} \mathrm{~B}$ across the combined sites was found, indicating that TP tended to increase with body mass regardless of taxonomy and larger coral reef fish in this Cape Eleuthera community on average fed at higher TPs.

The weak cross-species relationship between isotopic signatures and $\log _{2} M_{\max }$ suggested that maximum body mass could scarcely constrain species' trophic capabilities in this food web in which there were small-bodied benthivores and planktivores and large-bodied herbivores. The body-size structuring is similar to that of North Sea and Western Arabian Sea community data (Jennings et al. 2001; Al-Habsi et al. 2008). Here, the small size class biomass data were dominated by herbivores rather than higher TP omnivores such as Labridae (Graham et al. 2017), while the large size classes were dominated by piscivores and omnivores rather than large-bodied herbivores such as Scarinae (Hughes et al. 2007; Zhu 2019). Although the surveyed Cape Eleuthera sites are now legally protected, they were previously fished and are structurally degraded. The linearity of the $\delta^{15} \mathrm{~N}-\log _{2} \mathrm{~B}$ relationship at Cape Eleuthera may not be generic; it could be influenced by the loss of habitat structural complexity and aspects of past overfishing (e.g. removal of large herbivores).

The present study also had limitations. All individuals were treated as if they had the same isotopic baseline, yet significant isotopic differences between benthic and pelagic sources are expected (McConnaughey and McRoy 1979; Polunin and Pinnegar 2002), whereas other baselines would have been taken into consideration when estimating the trophic positions of consumers with significantly mixed diets. Also, for some species, sample sizes failed to adequately fulfil requirements for confidently describing stable isotope changes as a function of body mass (Galván et al. 2010), yet linear regression was still applied to these species to explore their $\delta^{15} \mathrm{~N}-\log _{2} \mathrm{M}$ relationships. Low sample sizes and/or size ranges $\left(r_{\mathrm{L}}\right)$ meant that for some species, stable isotope data could not be derived across whole UVC size ranges; for these stable isotope data were assumed to be size invariant. For missing species, the methods used to infer stable isotope values had limitations including species within the same genus or family having ontogenetic and/or dietary differences; some not meeting all three criteria and using published data from the same species could be subject to feeding strategies varying ontogenetically (Plass-Johnson et al. 2013) or spatially (Jennings et al. 1997; Matthews and Mazumder 2004). Unlike studies using combined baselines (Mill et al. 2007), here the benthic alga D. cavernosa was the sole baseline and this might not adequately represent the whole benthic assemblage, which includes turf algae, cyanobacteria and other potential production sources.

\section{Predator-prey mass ratio}

The mean PPMR at Cape Eleuthera indicates a relatively long food chain in this coral reef system compared with other aquatic systems (Table 5), suggesting potentially greater ecosystem size and stability (Jennings and Warr 2003). However, surveys at adjacent non-protected sites failed to show the presence of large predators there; thus, the PPMR data we report seem to be specific to the protected sites.

\section{Conclusions}

Stable isotope data indicate more than one production source and mixed reliance on them by some coral reef fishes suggesting evidence of reef fish crossing trophic boundaries described by their trophic guilds and that current categorisations are often simplistic. Combining visual census and stable isotope data indicated that the Cape Eleuthera coral reef fish community was size structured. The relationship at this site points to body size as a driver of predator-prey relationships and trophic pathways at community level, with the isotope data suggesting that trophic position plasticity is common at species level. This is the first indication of a positive linear $\delta^{15} \mathrm{~N}-\log _{2}$ body mass relationship in a coral reef system, but this may not pertain to all coral reefs.

Acknowledgements We thank Cape Eleuthera Institute (CEI) for providing logistic support, Jordan Atherton for underwater visual surveys, CEI interns involved in fish sampling, and local fishermen for providing fish samples.

Author contributions This study was designed by YZ and NVCP, the field work was carried out by $\mathrm{YZ}$, the data analysis was conducted by YZ, SPN and WDKR, and the paper was written by YZ, NVCP, WDKR and SPN.

Funding No external funding.

\section{Compliance with ethical standards}

Conflict of interest The authors declare that they have no conflicts of interest. 
Ethic approval All applicable international, national and/or institutional guidelines for the care and use of animals were followed. The research was approved by the Newcastle University Ethics Committee and the Bahamian Department of Marine Resources under permits MAMR/FIS/17 and MAMR/FIS/34A. No coral habitat was disturbed during this research. All fish were killed in accordance with the UK Home Office Scientific Procedures (Animal) Act. All samples were imported to UK under DEFRA permit TARP/2015/210.

Open Access This article is distributed under the terms of the Creative Commons Attribution 4.0 International License (http://creativeco mmons.org/licenses/by/4.0/), which permits unrestricted use, distribution, and reproduction in any medium, provided you give appropriate credit to the original author(s) and the source, provide a link to the Creative Commons license, and indicate if changes were made.

\section{References}

Al-Habsi SH, Sweeting CJ, Polunin NVC, Graham NAJ (2008) $\delta^{15} \mathrm{~N}$ and $\delta^{13} \mathrm{C}$ elucidation of size structured food webs in a Western Arabian Sea demersal trawl assemblage. Mar Ecol Prog Ser 353:55-63

Allen GR (1985) FAO species catalogue. Vol. 6. Snappers of the world: an annotated and illustrated catalogue of lutjanid species known to date. Food and Agriculture Organization of the United Nations (FAO). Fisheries Synopsis

Anderson TW, Carr MH (1998) BINCKE: a highly efficient net for collecting reef fishes. Environ Biol Fishes 51:111-115

Barnes C, Maxwell D, Reuman DC, Jennings S (2010) Global patterns in predator-prey size relationships reveal size dependency of trophic transfer efficiency. Ecology 91:222-232

Bates DM, Chambers JM, Hastie TJ (1992) Statistical models in S Comp Sci and Stat. In: Proceedings of the 19th symposium on the interface. Wadsworth \& Brooks California

Bearhop S, Adams CE, Waldron S, Fuller RA, MacLeod H (2004) Determining trophic niche width: a novel approach using stable isotope analysis. J Anim Ecol 73:1007-1012

Bell JD, Craik GJS, Pollard DA, Russell BC (1985) Estimating length frequency distributions of large reef fish underwater. Coral Reefs $4: 41-44$

Bode A, Carrera P, Lens S (2003) The pelagic foodweb in the upwelling ecosystem of Galicia (NW Spain) during spring: natural abundance of stable carbon and nitrogen isotopes. ICES J Mar Sci J Cons 60:11-22

Bode A, Carrera P, Porteiro C (2006) Stable nitrogen isotopes reveal weak dependence of trophic position of planktivorous fish on individual size: a consequence of omnivorism and mobility. Radioact Environ 8:281-293

Bronk DA, Glibert PM (1993) Application of a $15 \mathrm{~N}$ tracer method to the study of dissolved organic nitrogen uptake during spring and summer in Chesapeake Bay. Mar Biol 115:501-508

Cabana G, Rasmussen JB (1996) Comparison of aquatic food chains using nitrogen isotopes. Proc Natl Acad Sci 93:10844-10847

Charnov EL (1993) Life history invariants. Oxford University Press, Oxford

Chen L-S (2002) Post-settlement diet shift of Chlorurus sordidus and Scarus schlegeli (Pisces: Scardiae). Zool Stud 41:47-58

D’Agata S, Vigliola L, Graham NAJ, Wantiez L, Parravicini V, Villéger S, Mou-Tham G, Frolla P, Friedlander AM, Kulbicki M (2016) Unexpected high vulnerability of functions in wilderness areas: evidence from coral reef fishes. Proc R Soc B 1844:20160128
DeNiro MJ, Epstein S (1978) Influence of diet on the distribution of carbon isotopes in animals. Geochim Cosmochim Acta 42:495-506

DeNiro MJ, Epstein S (1981) Influence of diet on the distribution of nitrogen isotopes in animals. Geochim Cosmochim Acta 45:341-351

Dromard CR, Bouchon-Navaro Y, Harmelin-Vivien M, Bouchon C (2015) Diversity of trophic niches among herbivorous fishes on a Caribbean reef (Guadeloupe, Lesser Antilles), evidenced by stable isotope and gut content analyses. J Sea Res 95:124-131

Dunlap M, Pawlik JR (1998) Spongivory by parrotfish in Florida mangrove and reef habitats. Mar Ecol 19:325-337

Ferreira CEL, Goncçalves JEA, Coutinho R (2001) Community structure of fishes and habitat complexity on a tropical rocky shore. Environ Biol Fishes 61:353-369

France R, Chandler M, Peters R (1998) Mapping trophic continua of benthic food-webs: body size- $\delta^{15} \mathrm{~N}$ relationships. Mar Ecol Prog Ser 174:301-306

Freckleton RP (2000) Phylogenetic tests of ecological and evolutionary hypotheses: checking for phylogenetic independence. Funct Ecol 14:129-134

Froese R, Pauly D (2017) FishBase 2017, version (March, 2017). World Wide Web electronic publication

Fry B, Baltz DM, Benfield MC, Fleeger JW, Gace A, Haas HL, Quiñones-Rivera ZJ (2003) Stable isotope indicators of movement and residency for brown shrimp (Farfantepenaeus aztecus) in coastal Louisiana marshscapes. Estuaries 26:82-97

Galván DE, Sweeting CJ, Reid WDK (2010) Power of stable isotope techniques to detect size-based feeding in marine fishes. Mar Ecol Prog Ser 407:271-278

Graham NAJ, McClanahan TR, MacNeil MA, Wilson SK, Cinner JE, Huchery C, Holmes TH (2017) Human disruption of coral reef trophic structure. Curr Biol 27:231-236

Hadi TA, Tuti Y, Hadiyanto Abrar M, Suharti SR, Suharsono Gardiner NM (2018) The dynamics of coral reef benthic and reef fish communities in Batam and Natuna Islands, Indonesia. Biodiversity 19:1-14

Hesslein RH, Capel MJ, Fox DE, Hallard KA (1991) Stable isotopes of sulfur, carbon, and nitrogen as indicators of trophic level and fish migration in the lower Mackenzie River basin, Canada. Can J Fish Aquat Sci 48:2258-2265

Hiatt RW, Strasburg DW (1960) Ecological relationships of the fish fauna on coral reefs of the Marshall Islands. Ecol Monogr 30:65-127

Hughes TP, Baird AH, Bellwood DR, Card M, Connolly SR, Folke C, Grosberg R, Hoegh-Guldberg O, Jackson JBC, Kleypas J (2003) Climate change, human impacts, and the resilience of coral reefs. Science 301:929-933

Hughes TP, Rodrigues MJ, Bellwood DR, Ceccarelli D, Hoegh-Guldberg O, McCook L, Moltschaniwskyj N, Pratchett MS, Steneck RS, Willis B (2007) Phase shifts, herbivory, and the resilience of coral reefs to climate change. Curr Biol 17:360-365

Humann P, DeLoach N (1989) Reef fish identification: Florida. Caribbean, Bahamas

Jackson AL, Inger R, Parnell AC, Bearhop S (2011) Comparing isotopic niche widths among and within communities: SIBERstable isotope Bayesian ellipses in $R$. J Anim Ecol 80:595-602

Jennings S, Warr KJ (2003) Smaller predator-prey body size ratios in longer food chains. Proc R Soc Lond B Biol Sci 270:1413-1417

Jennings S, Grandcourt EM, Polunin NVC (1995) The effects of fishing on the diversity, biomass and trophic structure of Seychelles' reef fish communities. Coral Reefs 14:225-235

Jennings S, Reñones O, Morales-Nin B, Polunin NVC, Moranta J, Coll J (1997) Spatial variation in the ${ }^{15} \mathrm{~N}$ and ${ }^{13} \mathrm{C}$ stable isotope composition of plants, invertebrates and fishes on Mediterranean 
reefs: implications for the study of trophic pathways. Mar Ecol Prog Ser 146:109-116

Jennings S, Pinnegar JK, Polunin NVC, Boon TW (2001) Weak cross-species relationships between body size and trophic level belie powerful size-based trophic structuring in fish communities. J Anim Ecol 70:934-944

Jennings S, Greenstreet S, Hill L, Piet G, Pinnegar J, Warr KJ (2002a) Long-term trends in the trophic structure of the North Sea fish community: evidence from stable-isotope analysis, size-spectra and community metrics. Mar Biol 141:1085-1097

Jennings S, Pinnegar JK, Polunin NVC, Warr KJ (2002b) Linking sizebased and trophic analyses of benthic community structure. Mar Ecol Prog Ser 226:77-85

Jennings S, Warr KJ, Mackinson S (2002c) Use of size-based production and stable isotope analyses to predict trophic transfer efficiencies and predator-prey body mass ratios in food webs. Mar Ecol 240:11-20

Kulbicki M, Bozec Y-M, Labrosse P, Letourneur Y, Mou-Tham G, Wantiez L (2005) Diet composition of carnivorous fishes from coral reef lagoons of New Caledonia. Aquat Living Resour 18:231-250

Kürten B, Painting SJ, Struck U, Polunin NVC, Middelburg JJ (2013) Tracking seasonal changes in North Sea zooplankton trophic dynamics using stable isotopes. Biogeochemistry 113:167-187

Layman CA, Allgeier JE (2012) Characterizing trophic ecology of generalist consumers: a case study of the invasive lionfish in The Bahamas. Mar Ecol Prog Ser 448:131-141

Layman CA, Winemiller KO, Arrington DA, Jepsen DB (2005) Body size and trophic position in a diverse tropical food web. Ecology 86(9):2530-2535

Leal MC, Ferrier-Pagès C (2016) Molecular trophic markers in marine food webs and their potential use for coral ecology. Mar Genom 29:1-7

Leibold MA (1995) The niche concept revisited: mechanistic models and community context. Ecology 76:1371-1382

MacNeil MA, Graham NAJ, Cinner JE, Wilson SK, Williams ID, Maina J, Newman S, Friedlander AM, Jupiter S, Polunin NVC (2015) Recovery potential of the world's coral reef fishes. Nature 520:341-344

Matthews B, Mazumder A (2004) A critical evaluation of intrapopulation variation of $\delta^{13} \mathrm{C}$ and isotopic evidence of individual specialization. Oecologia 140:361-371

McClanahan TR, Hendrick V, Rodrigues MJ, Polunin NVC (1999) Varying responses of herbivorous and invertebrate-feeding fishes to macroalgal reduction on a coral reef. Coral Reefs 18:195-203

McClelland JW, Montoya JP (2002) Trophic relationships and the nitrogen isotopic composition of amino acids in plankton. Ecology 83:2173-2180

McConnaughey T, McRoy CP (1979) Food-web structure and the fractionation of carbon isotopes in the Bering Sea. Mar Biol 53:257-262

McCutchan JH, Lewis WM, Kendall C, McGrath CC (2003) Variation in trophic shift for stable isotope ratios of carbon, nitrogen, and sulfur. Oikos 102:378-390

McMeans BC, McCann KS, Tunney TD, Fisk AT, Muir AM, Lester N, Shuter B, Rooney N (2016) The adaptive capacity of lake food webs: from individuals to ecosystems. Ecol Monogr 86:4-19

Mill AC, Pinnegar J, Polunin NVC (2007) Explaining isotope trophicstep fractionation: why herbivorous fish are different. Funct Ecol 21:1137-1145

Minagawa M, Wada E (1984) Stepwise enrichment of $15 \mathrm{~N}$ along food chains: further evidence and the relation between $\delta^{15} \mathrm{~N}$ and animal age. Geochim Cosmochim Acta 48:1135-1140

Mouillot D, Villéger S, Parravicini V, Kulbicki M, Arias-González JE, Bender M, Chabanet P, Floeter SR, Friedlander A, Vigliola L (2014) Functional over-redundancy and high functional vulnerability in global fish faunas on tropical reefs. Proc Natl Acad Sci 111:13757-13762

Moustaka M, Langlois TJ, McLean D, Bond T, Fisher R, Fearns P, Dorji P, Evans RD (2018) The effects of suspended sediment on coral reef fish assemblages and feeding guilds of north-west Australia. Coral Reefs 37:1-15

Munday PL (2001) Fitness consequences of habitat use and competition among coral-dwelling fishes. Oecologia 128:585-593

Newman SP, Handy RD, Gruber SH (2012) Ontogenetic diet shifts and prey selection in nursery bound lemon sharks, Negaprion brevirostris, indicate a flexible foraging tactic. Environ Biol Fishes 95:115-126

Newsome SD, Martinez del Rio C, Bearhop S, Phillips DL (2007) A niche for isotopic ecology. Front Ecol Environ 5:429-436

Parnell A, Jackson A (2013) siar: Stable isotope analysis in R. R package version 4.2.2

Pastorok RA, Bilyard GR (1985) Effects of sewage pollution on coral-reef communities. Mar Ecol Prog Ser 21:175-189

Peters RH (1986) The ecological implications of body size. Cambridge University Press, Cambridge

Plass-Johnson JG, McQuaid CD, Hill JM (2013) Stable isotope analysis indicates a lack of inter-and intra-specific dietary redundancy among ecologically important coral reef fishes. Coral Reefs 32:429-440

Polunin NVC (1996) Trophodynamics of reef fisheries productivity reef fisheries. Springer, Berlin, pp 113-135

Polunin NVC, Pinnegar JK (2002) Trophic ecology and the structure of marine food webs. Handb Fish Biol Fish Fish Biol 1:301-320

Post DM (2002) Using stable isotopes to estimate trophic position: models, methods, and assumptions. Ecology 83:703-718

R Core Team (2016) R: a language and environment for statistical computing. In: Computing RFfS (ed)

Reid WDK, Sweeting CJ, Wigham BD, McGill RAR, Polunin NVC (2016) Isotopic niche variability in macroconsumers of the East Scotia Ridge (Southern Ocean) hydrothermal vents: What more can we learn from an ellipse? Mar Ecol Prog Ser 542:13-24

Reum JCP, Jennings S, Hunsicker ME (2015) Implications of scaled $\delta^{15} \mathrm{~N}$ fractionation for community predator-prey body mass ratio estimates in size-structured food webs. J Anim Ecol 84(6):1618-1627

Ríos MF, Venerus LA, Karachle PK, Reid WDK, Erzini K, Stergiou KI, Galván DE (2019) Linking size-based trophodynamics and morphological traits in marine fishes. Fish Fish 20:355-367

Robertson DR (1982) Fish feces as fish food on a Pacific coral reef. Mar Ecol Prog Ser 7:253-265

Robinson JPW, Baum JK (2015) Trophic roles determine coral reef fish community size structure. Can J Fish Aquat Sci 73:496-505

Rolff C (2000) Seasonal variation in $\delta^{13} \mathrm{C}$ and $\delta^{15} \mathrm{~N}$ of size-fractionated plankton at a coastal station in the northern Baltic proper. Mar Ecol Prog Ser 203:47-65

Romanuk TN, Hayward A, Hutchings JA (2011) Trophic level scales positively with body size in fishes. Glob Ecol Biogeogr 20(2):231-240

Stamoulis KA, Friedlander AM, Meyer CG, Fernandez-Silva I, Toonen RJ (2017) Coral reef grazer-benthos dynamics complicated by invasive algae in a small marine reserve. Sci Rep 7:43819

Strieder Philippsen J, Benedito E (2013) Discrimination factor in the trophic ecology of fishes: a review about sources of variation and methods to obtain it. Oecol Aust 17:205-2016

Sweeting CJ, Polunin NVC, Jennings S (2006) Effects of chemical lipid extraction and arithmetic lipid correction on stable isotope ratios of fish tissues. Rapid Commun Mass Spectrom 20:595-601

Tieszen LL, Boutton TW, Tesdahl KG, Slade NA (1983) Fractionation and turnover of stable carbon isotopes in animal tissues: implications for $\delta^{13} \mathrm{C}$ analysis of diet. Oecologia 57:32-37

Trebilco R, Baum JK, Salomon AK, Dulvy NK (2013) Ecosystem ecology: size-based constraints on the pyramids of life. Trends Ecol Evol 28:423-431

Wickham H, Chang W (2016) ggplot2: Create elegant data visualisations using the grammar of graphics. R package version 2.2. 1. https:// CRAN.R-project.org $/$ package $=$ ggplot 2 
Wilkinson GN, Rogers CE (1973) Symbolic description of factorial models for analysis of variance. J R Stat Soc Ser C (Appl Stat) 22:392-399

Wulff JL (1997) Parrotfish predation on cryptic sponges of Caribbean coral reefs. Mar Biol 129:41-52

Zhu Y (2019) Studies in the stable isotope ecology of coral reef fish food webs. PhD thesis, Newcastle University, Newcastle upon Tyne (under review)
Publisher's Note Springer Nature remains neutral with regard to jurisdictional claims in published maps and institutional affiliations. 